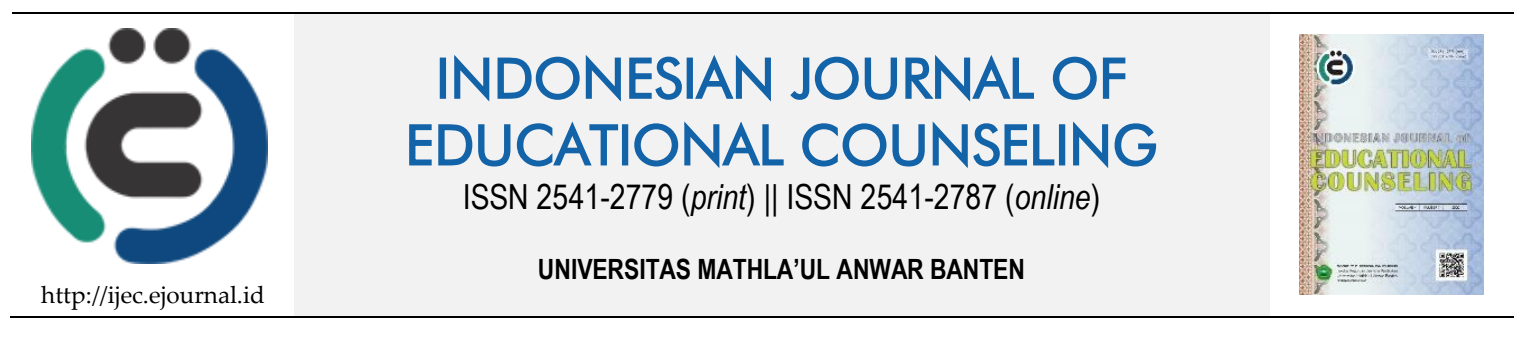

Theoretıcal/Conceptual Artıcle

\title{
Peran Konselor dalam Perspektif Hadist Akhir Zaman
}

\author{
Muhammad Andri Setiawan ${ }^{1}$ \\ 1 Universitas Lambung Mangkurat, Indonesia
}

\begin{tabular}{|c|c|}
\hline Article History & ABSTRACT \\
\hline \multirow[t]{2}{*}{$\begin{array}{l}\text { Received: } 27.06 .2019 \\
\text { Received in revised form: } \\
12.07 .2019 \\
\text { Accepted: } 06.01 .2020 \\
\text { Available online: } 28.01 .2020\end{array}$} & $\begin{array}{l}\text { THE ROLE OF COUNSELOR IN THE PERSPECTIVE OF AKHIR ZAMAN } \\
\text { HADITH. This literature review addresses the role of the counselor by pressing } \\
\text { on a number of common phenomena that occur today. This phenomenon turns } \\
\text { out to correspond to a number of "akhir zaman" hadiths. Of course, with this } \\
\text { description, you will increasingly realize that the role of counselor is very much } \\
\text { needed now to deal with student dynamics. The 'akhir zaman' characters in } \\
\text { question include: (1) aspects of humanitarian setbacks caused by drugs; (2) the } \\
\text { fading of the tradition of family life and social interaction tends to be } \\
\text { individualistic, thus requiring solutions to Islamic values and norms } \\
\text { themselves but should be structured by involving school components reflected } \\
\text { in the school's vision and mission; (3) the choice of social context needs to be } \\
\text { formulated in depth which places the teachings of Islam as a whole without } \\
\text { compromising the teachings of Islam as a religion of da'wah; and finally, (4) } \\
\text { massive relationships that emphasize strong interpersonal relationships } \\
\text { between counselors and students and subject teachers. }\end{array}$ \\
\hline & $\begin{array}{l}\text { KEYWORDS: Akhir Zaman, Counselors, Guidance and Counseling Services, } \\
\text { Students. }\end{array}$ \\
\hline
\end{tabular}

DOI: 10.30653/001.202041.96

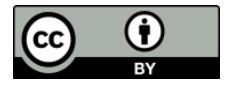

This is an open access article distributed under the terms of the Creative Commons Attribution 4.0 International License, which permits unrestricted use, distribution, and reproduction in any medium, provided the original work is properly cited. (c) 2020 Muhammad Andri Setiawan.

\section{PENDAHULUAN}

Pada Peraturan Menteri Pendidikan dan Kebudayaan Republik Indonesia Nomor 111 tahun 2014 tentang Bimbingan dan Konseling pada Pendidikan Dasar dan Pendidikan Menengah bahwa bimbingan dan konseling didefinisikan sebagai upaya sistematis, objektif, logis, dan berkelanjutan serta terprogram yang dilakukan oleh konselor atau guru Bimbingan dan Konseling untuk memfasilitasi perkembangan siswa/Konseli untuk mencapai kemandirian dalam kehidupannya.

Mengacu pada Peraturan Kemendikbud di atas maka peran konselor atau guru Bimbingan dan Konseling mengandung peran yang begitu signifikan dalam menentukan arah pendidikan yang mengacu pada pertumbuhan dan perkembangan siswa, yang menunjukkan sinergis semua bidang/pilar pendidikan. Berkenaan dengan bidang/pilar

${ }^{1}$ Corresponding author's address: Program Studi Bimbingan dan Konseling, FKIP Universitas Lambung Mangkurat. Jl. Brigjen Hasan Basri Kampus FKIP 2 Kotak Pos 87, Banjarmasin, Kalimantan Selatan, Indonesia. Email: andri.bk@ulm.ac.id 
pendidikan, dikatakan oleh Nurihsan (2006, p. 4) bahwa pencapaian standar kemampuan profesional/akademis dan tugas-tugas perkembangan siswa, memerlukan kerja sama yang harmonis antara pengelola dan pelaksana manajemen pendidikan, pembelajaran dan bimbingan sebab ketiganya merupakan bidang-bidang utama dalam pencapaian tujuan pendidikan. Penjelasan tentang hubungan ketiga bidang/pilar tersebut dapat disimak melalui gambar yang diilustrasikan oleh Tim Penyusun (2007: 1) di bawah ini.

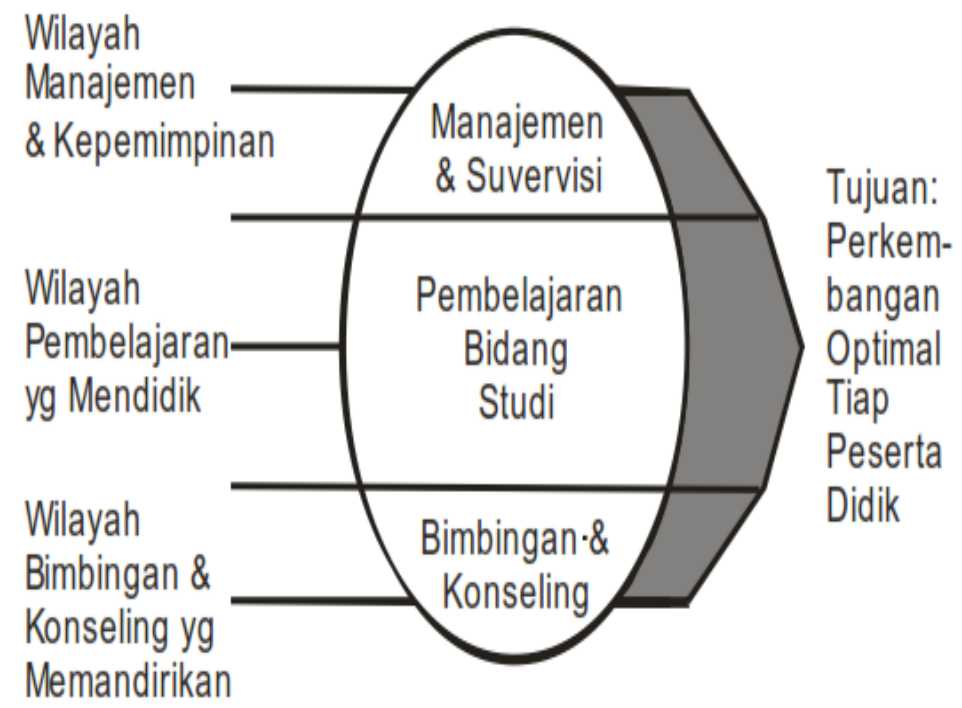

\section{Gambar 1.Tiga Bidang/Pilar Pendidikan}

Keberadaan Bimbingan dan Konseling yang memuat pada tantangan perkembangan optimal tiap siswa, sudah tentu akan dihadapi dengan persoalan mendasar sehingga sinergis tiga bidang/pilar pendidikan mutlak diperlukan, sehingga dengan demikian permasalahan yang dihadapi oleh siswa tidak hanya berkutat pada permasalahan pada bidang pendidikan yang dibatasi lingkup institusi pendidikan tetapi juga mempersiapkan siswa menghadapi tantanngan global, yang hampir dapat dikatakan sebagai akumulasi dari berbagai krisis moral, banyak para ahli bimbingan dan konseling merumuskan keberadaan bimbingan dan konseling sebagai jawaban atas tantangan dari tuntutan zaman atas kebutuhan pendidikan.

Secara implisit Mahdi (2017, pp. 3-4) menanggapi bahwa pengembangan kompetensi hidup memerlukan sistem layanan pendidikan pada satuan pendidikan yang tidak hanya mengandalkan layanan pembelajaran mata pelajaran/bidang studi dan manajemen saja, tetapi juga layanan khusus yang bersifat psiko-edukatif melalui layanan bimbingan dan konseling. Berbagai aktivitas bimbingan dan konseling dapat diupayakan untuk mengembangkan potensi dan kompetensi hidup siswa yang efektif serta memfasilitasi mereka secara sistematik, terprogram, dan kolaboratif agar setiap siswa atau konseli betul-betul mencapai kompetensi perkembangan atau pola perilaku yang diharapkan. Diungkapkan oleh Tohirin (2013, pp. 2-10) terdapat lima tantangan terbesar bimbingan dan konseling dalam pendidikan, yakni sebagai berikut:

1) Perkembangan IPTEKS menimbulkan perubahan dalam berbagai sendi kehidupan sehingga memerlukan adanya layanan bimbingan dan konseling. 
2) Prosedur pelayanan bimbingan dan proses konseling dalam pendidikan berkaitan erat dengan hakikat makna dan fungsi pendidikan dalam keseluruhan aspek kehidupan untuk mencapai perwujudan manusia utuh (kaffah).

3) Eksistensi peran pendidik (guru) di sekolah yakni mendidik sekaligus mengajar, yaitu membantu siswa mencapai kedewasaan. Pada perkembangannya seiring dengan makin kuatnya keberadaan guru sebagai pendidik maka amat tidak memungkinkan bila menempatkan dua fungsi guru dalam proses pembelajaran. Oleh karena itu, penempatan fungsi pembimbing perlu menempatkan mereka yang berlatar kesarjanaan dan keprofesian bimbingan dan konseling.

4) Proses pendidikan sangat berhubungan dengan faktor psikologis karena memandang siswa sebagai pribadi unik dengan segala karakteristiknya, yang menimbulkan problem psikologis dan hanya bisa dientaskan melalui pendekatan psikologis dan konseling.

5) Permasalahan belajar sangatlah kompleks karena melibatkan faktor internal, ekternal, psikologis dan sosiologis sudah tentu memerlukan penanganan intensif dan terencana dengan baik melalui bimbingan dan konseling.

Konstalasi problematika siswa senantiasa dihubungkankan dengan kondisi 'di depan mata' yang terkoneksi dengan situasi terkini sehingga tantangan keberadaan bimbingan dan konseling senantiasa berubah-ubah. Tentu saja pada kenyataan praktis hal ini dapat dibenarkan, namun pada sisi berlawanan urgensi bimbingan dan konseling dalam pendidikan bukan hanya menyiapkan kondisi siswa tersebut tapi juga mengungkap kematangan diiri siswa sebagai manusia utuh. Keutuhan manusia secara paripurna hanya dapat diungkap melalui sandaran perspektif Sang Pencipta. Rohman (2016, p. 147) menyebutkan bahwa essensi dengan cara memberdayakan (empowering) iman, akal, dan kemauan yang dikaruniakan oleh Allah kepadanya untuk mempelajari tuntunan Allah dan Rasul-Nya. Hal tersebutlah mendasari diperlukan bimbingan dan konseling menggunakan pendekatan Islam.

Namun permasalahannya apabila praktisi guru bimbingan dan konseling atau konselor sekolah tidak menyikapinya dengan penuh kehati-hatian, hal ini akan menjadikan pendekatan Islam yang digagas hanya sampai pada permukaannya saja tidak keseluruhan gerak tuntutan ajaran Islam. Pembicaraan ini dapat diwujudkan apabila guru bimbingan dan konseling serta konselor sekolah memiliki pengertian mendalam tentang hakikat permasalahan siswa yang berkorelasi dengan kondisi zaman. Ajaran Islam dengan kesempurnaannya telah menggariskan sejumlah permasalahan yang timbul apabila tidak mengikuti ajaran Islam. Rasulullah Saw telah ber-nubuwwah tentang sikap yang ditunjukkan umat manusia sepeninggal beliau. Inilah yang seringkali diutarakan sebagai hadist akhir zaman. Berangkat dari uraian di atas maka artikel ini menelaah tentang peran konselor dan permasalahan siswa di sekolah dalam perspektif hadist akhir zaman.

\section{KAJIAN LITERATUR}

\section{Urgensi Hadist Akhir Zaman}

Mempelajari hadist akhir zaman dan mendasarinya sebagai upaya menyikapi fenomena yang terjadi dewasa ini merupakan keharusan yang sebaiknya dilakukan kajian 
keilmuan yang erat berhubungan dengan perilaku manusia seperti ilmu sosialhumaniora, sehingga para ahli pada bidang ini dapat menjadikan pijakan untuk mendeskripsikan perilaku dan juga mungkin solusi ketika perilaku tersebut terjadi. Kita tentu akan menyadari hal ini akan sulit dilakukan apabila para ahli ilmu sosial-humaniora tidak memiliki keyakinan akan Al Qur'an dan Al Hadist.

Pada akhirnya apabila hadist akhir zaman dilakukan untuk menyikapi fenomana yang terjadi pada akhirnya menjadi titik temu menjadikan Islam sebagai way of life. Khusus dalam bimbingan dan konseling maka akan menjadi semakin penting menyadari 'hakikat manusia' dan keutuhan pendekatan Islam hingga ketataran praktis sehingga tidak terjebak retrotika dan kajian filosofis.

Setiawan (25 April 2018) menunjukkan setidaknya ada lima urgensi penting menempatkan hadist akhir zaman, dalam upaya memahami duduk perkaran fenomana kemunduran kemanusiaan selama ini, yakni sebagai berikut.

1) Bagian penting dari hierarki esensi kebenaran ajaran islam, iman dan ihsan (perilaku terpuji sehingga merasa perbuatan di dunia akan senantiasa diawasi Allah) sehingga nyatalah kemutlakan kebenaran ajaran Islam apabila ditopang dengan wawasan mumpuni tentang hadits mengenai tanda-tanda akhir zaman.

2) Bentuk keimanan seseorang pada hal gaib. Tanda-tanda akhir zaman yang termaktub dalam hadits-hadits nabi, adalah perkara ghaib yang seharusnya diyakini. Jadi, mempelajari hadits-hadits akhir zaman, adalah bagian dari upaya pembuktian iman dan mencapai derajat takwa.

3) Persiapan diri dan bentuk antisipasi sebelum fenomena itu terjadi. Tentunya ini menarik bagi kalangan ilmuwan sosial-humaniora untuk mengkaji suatu peristiwa dan perilaku.

4) Bahan ajar pengingat lintas generasi. Hadits-hadits akhir zaman begitu penting diajarkan sebagai pengingat lintas generasi. Sejak zaman Nabi Saw hingga sekarang, memori tentang hadits akhir zaman masih tersimpan dengan baik karena masalah ini selalu diajarkan.

5) Mengetahui peta akhir zaman. Hadits-hadits akhir zaman, mengajarkan umat Islam mengenai pentingnya memahami peta akhir zaman. Melalui peta ini, umat Islam tidak gampang terpukau dan terkecoh dengan apa yang dilakukan oleh musuh-musuh (baik positif maupun negatif).

Walaupun dikatakan memahami fenomena dan realita sekarang melalui pemahaman akhir zaman dikatakan sangat urgen namun tetap saja diperlukan kehatihatian. Ihsan (2018) menerangkan bahwa perlu diwaspadai agar tidak terlalu cepat mencocokkan realita dengan hadits tanpa adanya kajian yang mendalam. Melihat satu kecocokan antara keduanya, kemudian langsung menghukumi bahwa yang dimaksud dengan hadits tersebut adalah realita tersebut. Setidaknya untuk melakukan pencocokan harus melalui beberapa tahap dan rambu-rambu, diantaranya adalah sebagai berikut.

1) Mengkaji kecocokan hadits dengan realita secara komprehensif dengan cara mengumpulkan riwayat-riwayat serupa yang shahih dan saling berkaitan.

2) Tidak Memvonis adanya kecocokan antara nash dengan realita kecuali ada dalil yang kuat. 
3) Untuk sampai pada pemahaman yang benar dalam menyikapi nash-nash akhir zaman, maka harus melihat urutan-urutan yang disebutkan di dalam hadits.

4) Adanya kecocokan antara tragedi akhir zaman dengan sebuah hadits adalah suatu perkara, sementara menyampaikan kecocokan tersebut kepada umat adalah perkara lain dengan mempertimbangkan pertimbangan manfaat dan dampak yang timbulkan.

\section{Beberapa Hadist Akhir Zaman Berhubungan Permasalahan Siswa}

Menarik untuk disimak bahwa permasalahan yang menimpa umat manusia sekarang ini berhubungan dengan latar belakang keberadaan bimbingan dan konseling. Hal ini diungkapkan oleh Tim Penyusun (2007: 16-17) bahwa perkembangan konseli tidak lepas dari pengaruh lingkungan, baik fisik, psikis maupun sosial. Sifat yang melekat pada lingkungan adalah perubahan. Perubahan yang terjadi dalam lingkungan dapat mempengaruhi gaya hidup (life style) warga masyarakat. Apabila perubahan yang terjadi itu sulit diprediksi, atau di luar jangkauan kemampuan, maka akan melahirkan kesenjangan perkembangan perilaku konseli, seperti terjadinya stagnasi (kemandegan) perkembangan, masalah-masalah pribadi atau penyimpangan perilaku. Perubahan lingkungan yang diduga mempengaruhi gaya hidup, dan kesenjangan perkembangan tersebut, diantaranya: pertumbuhan jumlah penduduk yang cepat, pertumbuhan kotakota, kesenjangan tingkat sosial ekonomi masyarakat, revolusi teknologi informasi, pergeseran fungsi atau struktur keluarga, dan perubahan struktur masyarakat dari agraris ke industri.

Iklim lingkungan kehidupan yang kurang sehat, seperti: maraknya tayangan pornografi di televisi dan VCD; penyalahgunaan alat kontrasepsi, minuman keras, dan obat-obat terlarang/narkoba yang tak terkontrol; ketidak harmonisan dalam kehidupan keluarga; dan dekadensi moral orang dewasa sangat mempengaruhi pola perilaku atau gaya hidup konseli (terutama pada usia remaja) yang cenderung menyimpang dari kaidah-kaidah moral (akhlak yang mulia), seperti: pelanggaran tata tertib Sekolah/Madrasah, tawuran, meminum minuman keras, menjadi pecandu Narkoba atau NAPZA (Narkotika, Psikotropika, dan Zat Adiktif lainnya, seperti: ganja, narkotika, ectasy, putau, dan sabu-sabu), kriminalitas, dan pergaulan bebas (free sex).

Beberapa permasalahan di atas merupakan ilustrasi mendasar perlunya bimbingan dan konseling di institusi pendidikan, apabila kita kembalikan kepada hadist akhir zaman diantaranya sebagai berikut:

\section{Perkembangnya 'khamar' dalam bentuk yang beragam dan berbeda}

Dari Abu Umamah Al Bahili Ra, Rasulullah Saw bersabda: "Malam dan siang tidak akan pergi (dunia tidak akan hancur), sehingga segolongan umatku meminum khmar dan mereka menamainya dengan selain namannya." (HR. Abu Dawud [Al-Mubayyadh, 2014, p. 249]).

Seperti yang dikemukakan Rasulullah Saw, di masa sekarang hal-hal yang memabukkan tidak lagi minuman keras. Semakin berkembang zaman semakin berkembang pula minuman memabukkan (yang sekarang disebut minuman beralkohol dan narkotika). Dari bentuk ada yang menyerupai air, butiran garam hingga tablet sampai kapsul, sedangkan cara mengonsumsi juga beragam ada yang diminum, ditelan, dihisap bahkan ada juga yang disuntik dengan jarum. Bahkan ironisnya di masa sekarang ada 
sekelompok oknum yang berupaya melegalkan narkotika sebagai bentuk pemeliharaan kesehatan fisik dan kesehatan mental.

Ditegaskanpula pada hadist: dari Aisyah $R a$, dia berkata, Rasulullah Saw bersabda: "Sesungguhnya yang pertamakali direkadaya dalam agama Islam sebagaimana wadah yang direkadaya adalah masalah khmar." Maka ditanyakanlah kepada Rasulullah Saw, "Bagaimana hal itu bisa terjadi padahal keharamannya sungguh jelas?" Beliau menjawab, "Mereka menyebutnya bukan dengan namanya." (HR. Ad-Darimi [Al-Mubayyadh, 2014, p. 249]).

\section{Berkembangnya dunia hiburan ('entertainment')}

Dari Imran Bin Hushain Ra, Rasulullah Saw bersabda: "Pada umatku ini akan terjadi pembenaman ke perut bumi, penjelmaan menjadi makhluk lain, serta hujan batu dari langit." Maka berkatalah salah seorang sahabat,"Wahai Rasulullah, kapan hal itu terjadi?" Beliau menjawab,"Jika para penyanyi dan pemain musik banyak bermuculan dan ketika khamr dijadikan minuman." (HR. At Tirmidzi [Al-Mubayyadh, 2014, p. 249]).

Kalau dari dulu hiburan hanya dikenal musik, drama, komedi dan seni tari, di masa sekarang industri hiburan berkembang pesat lebih-lebih sering dengan perkembangan media cetak, media elektronik hingga media elektronik. Tontonan pun makin beragam dan lebih variatif dari yang mendidik sampai dengan merusak. Di dunia entertainment menyajikan penampilan aktor dan aktris yang tampan, cantik dan muda nyaris tanpa cela dengan memperlihatkan properti mewah dengan hanya yang lumayan mewah. Gaya hidup, trend dan sikap mereka (selebritis) menjadi panutan. Sementara itu, promosi kehidupan bebas tanpa nilai dan etika juga diperlihatkan oleh mereka. Beberapa di antara mereka memiliki fans seperti pengikut yang fanatik.

\section{Sibuk menjaga penampilan fisik namun melupakan akhlak}

Dari Ibnu Abbas Ra yang berkata: Rasulullah Saw bersabda: "Akan ada orang-orang di akhir zaman yang menyemir rambut, dengan warna hitam, seperti tembolok merpati, mereka tidak mencium bau surga." (HR. Ahmad dan Abu Daud [Azhim, 2004, p. 108]).

Pada zaman akhir ini banyak ditemui orang-orang yang berusia senja yang senantiasa menjaga penampilan dan kebugaran mereka. Mereka mengikuti mode dan fashion yang terus berkembang, ataupun dilakukan untuk menjaga penampilan tak heran mereka melakukan operasi ratusan kali dengan biaya yang tak sedikit. Kalau di masa dulu orang yang memasuki usia senja biasanya menggunakan semir rambut dan rambut palsu (wig), namun sekarang penampilan termasuk kulit untuk tidak mengerut sehingga tandatanda penuan tidak tampak. Orang seperti ini tidak peduli kalau harus memasukkan zatzat kimia yang berbahaya dan haram ke dalam tubuh mereka yang penting penampilan prima.

\section{Meluasnya pergaulan bebas}

Tersebut pada hadist yang dikemukakan dari Nawas bin Sam'an Ra, Rasulullah Saw bersabda: "Tinggallah manusia-manusia jahat yang melakukan hubungan seksual dan banyak kawin seperti keledai, pada masa merekalah kiamat terjadi."(HR. Muslim). 
Pada abad-abad ini, seiring dengan meluasnya peradaban dan pemikiran Barat ke seluruh dunia juga berkembang pula paham kebebasan seks yang merupakan dampak bawaannya. Generasi muda sangat rentan dengan pergaulan bebas, hal ini dimulai dengan kegiatan pacaran sebagai hubungan tanpa ikatan. Seseorang dengan mudah melepaskan nafsu seks sama halnya seperti makan dan minum tanpa menunggu masa pernikahan. Kesucian bukan lagi kata yang disakral yang harus dihormati, akibatnya pencarian cinta kasih sama halnya dengan petualangan seks. Nilai kemanusiaan akhirnya hilang seiring dengan pemerosotan akhlak, tak ubahnya manusia seperti binatang. Seiring dengan kebebasan seks berkembang pula perilaku seks yang menyimpang hingga industri pornografi dan prostitusi sebagai sesuatu yang dilazimkan dan wajar diterima manusia.

\section{Sikap individualisme dalam pergaulan}

Dari Abdullah Bin Amr Ra, Rasulullah Saw bersabda,"Hari kiamat tidak akan tiba sehingga orang yang dapat dipercayai didustakan sedangkan orang-orang yang berkhianat justru dipercaya, kemesuman dan kata-kata kotor merupakan fenomena umum ditengah masyarakat, terputusnya tali silaturrahmi dan hubungan bertetangga yang buruk." (HR. Ahmad [Al-Mubayyadh, 2014, pp. 279-280]).

Hubungan sosial mengalami krisis sebab masing-masing manusia lebih mementingkan diri sendiri, Said Abdul Azhim (2004: 107) mengatakan manusia telah melakukan dosa-dosa dan maksiat-maksiat secara terang-terangan, bahkan membanggabanggakannya, mereka memutuskan apa yang diperintahkan oleh Allah untuk disambungkan, anak-anak menjauhi orang tua mereka, sehingga bertahun-tahun atau berbulan-bulan berlalu, mereka tidak pernah berkunjung kepada orang tua, begitu pula kepada seluruh kerabat. Adapun buruknya hubungan bertetangga, silakan berbicara, banyak sekali contohnya. Alangkah banyaknya tetangga yang tidak mengenal tetangganya, tidak memperhatikan keadaannya, yang dengan begitu mereka telah menyelisihi Kitab Allah dan Sunah Rasulullah Saw.

Individualisme terlihat secara nyata tatkala antar manusia memberi salam kepada mereka yang saling mengenal, sebagaimana disebutkan dari Ibnu Mas'ud Ra, bersabda Rasulullah Saw: "Diantara tanda-tanda hari kiamat adalah seorang laki-laki tidak akan mengucapkan salam kepada orang lain kecuali hanya kepada orang yang dia kenal." (HR. Ahmad [Al-Mubayyadh, 2014, p. 267]).

Apakah yang harus kita lakukan ketika menghadapi masa individualisme? Rasulullah Saw menganjurkan agar kita bersabar, sebagaimana yang disebutkan dari Usa'id Bin Hudhair Ra dikisahkan: "Seorang laki-laki Anshar datang menemui Rasulullah Saw seraya berkata,"Ya Rasulullah, apakah Anda tidak mengangkatku sebagai pegawai seperti yang Anda lakukan kepada si Fulan?" Beliau menjawab, "Ketahuilah, engkau akan menemui zaman inividualisme sepeninggalku. Maka pada saat itu, bersabarlah engkau hingga engkau bertemu denganku di Al Haudh (telaga di surga)." (HR. Bukhari).

\section{Peranan Konselor dalam Pendidikan}

Menilik pada kenyataan di atas maka betapa berat peran konselor menghadapi konseli dalam suasana akhir zaman. Akan tetapi bukan suatu keniscayaan konselor sekolah dipandang sebagai garda terdepan dalam menyiapkan konseli khususnya siswa. 
Kiranya benar seperti diungkapkan oleh Tim Penyusun (2007: 18) bahwa upaya menangkal dan mencegah perilaku-perilaku yang tidak diharapkan adalah mengembangkan potensi konseli dan memfasilitasi mereka secara sistematik dan terprogram untuk mencapai standar kompetensi kemandirian. Upaya ini merupakan wilayah garapan bimbingan dan konseling yang harus dilakukan secara proaktif dan berbasis data tentang perkembangan konseli beserta berbagai faktor yang mempengaruhinya.

Sungguh wajar kemudian sosok utuh konselor dianggap prima apabila memiliki kompetensi pedagogik, kepribadian, sosial dan keprofesionalan secara secara seimbang (Peraturan Menteri Pendidikan Nasional Republik Indonesia Nomor 27 Tahun 2008 tentang Standar Kualifikasi Akademik dan Kompetensi Konselor), ketika berhadapan dengan permasalahan siswa sesuai dengan deskripsi hadist akhir zaman. Guru bimbingan dan konseling walau bagaimanapun adalah pendidik yang memiliki tanggung jawab bersama-sama dengan guru mata pelajaran mengimplementasikan nilai-nilai karakter cerdas dalam proses pembelajaran maupun dalam kegiatan pelayanan bimbingan dan konseling (Redjeki, 2013, p. 57).

Menurut kesimpulan dari Bor, et. al (2002, pp. 13-14) yang dihadapi oleh konselor sekolah pada setting pendidikan adalah sebagai berikut.

1) Penanganan konselor sekolah sangat kompleks dan beragam yang bisa saja tidak berkaitan dengan permasalahan belajar dan peminatan karier diantaranya adalah masalah persahabatan, bullying, dinamika keluarga, penyakit fisik, kematian orang yang dicintai, kehidupan seks, relasi orientasi seksual, anoreksia, penyalahgunaan obat-obatan dan tekanan tuntutan pendidikan.

2) Masalah-masalah tersebut memiliki implikasi dimensi luas yang mencakup hubungan antara para siswa dengan anggota keluarga dan para pendidik serta para siswa lain, sehingga seorang konselor sekolah tidak dapat memandang siswa sebagai konseli dalam arti tunggal tetapi juga sebagai bagian dari konstalasi yang saling terhubung.

3) 'Keluarga' dipandang sebagai sistem sosial yang paling penting bagi siswa di institusi pendidikan. Definisi keluarga memiliki makna yang lebih luas karena tidak hanya diartikan sebagai suatu relasi yang berkenaan dengan hubungan darah tetapi juga memiliki makna yang lebih luas yakni hubungan sosial, yang terakhir tentu saja direpresentatifkan institusi pendidikan dan dinamika pergaulan sosial di dalamnya.

4) Konselor sekolah ketika menjalankan perannya dalam prosedur pelayanan bimbingan dan prosedur proses konseling lebih dituntut untuk memperhatikan konteks sosial siswa. Konteks sosial dapat memberikan makna mendalam terhadap masalah psikologis siswa dan secara dominan menyediakan berbagai kemungkinan solusi untuk permasalahan siswa.

5) Secara normatif institusi pendidikan memiliki sejumlah peraturan dan ketentuan yang bisa jadi akan berbeda dengan mekanisme pelaksanaan bimbingan dan konseling. Hal tersebut terutama berkenaan dengan pandangan terhadap siswa dan kode etik dalam menyimpan kerahasiaan. Tentu saja akan berbenturan pula dengan pelaksanaan praktek terutama panjang sesi dan durasi prosedur proses konseling, maka menjadi penting bagi konselor sekolah untuk dapat beradaptasi dan menghormati segala ketentuan pengaturan dari institusi pendidikan. 
6) Memang terdapat beberapa prosedur pelayanan dan prosedur proses yang mungkin membutuhkan sesi khusus dan durasi yang panjang, maka seorang konselor sekolah perlu mempertimbangkan segala prosedur pelayanan bimbingan dan prosedur proses konseling dengan penuh pertimbangan dan kehati-hatian.

7) Berkenaan dengan deskripsi yang dijelaskan pada poin enam tersebut, maka pelaksanaan bimbingan dan konseling dalam setting pendidikan hendaknya memiliki tujuan yang jelas dan tujuan tersebut selaras dengan peraturan dan kebijakan pendidikan secara generalis. Hal ini dapat dikaitkan dengan definisi masalah atau perubahan definisi masalah. Namun disatu sisi tetap mempertahankan independensi pelaksanaan bimbingan dan konseling. Konselor sekolah dituntut untuk memiliki rancangan program yang bersifat fleksibel dan berkesinambungan.

8) Tugas konselor sekolah yang utama adalah membantu siswa mengidentifikasi sesuatu yang dianggap berarti dan berpotensi menjadi masalah bagi mereka dan konsekuensi yang ditimbulkannya. Titik tekan dari tugas ini adalah membantu siswa untuk menghindarkan situasi siswa untuk memiliki corak pandang yang mungkin 'destruktif' baik disengaja maupun tidak disengaja dengan tetap mempertahankan prioritas ide dan gagasan yang bersumber dari siswa sendiri.

9) Dalam beberapa kondisi konselor sekolah dituntut untuk dapat mempertanggungjawabkan kegiatan profesionalisme dengan tetap mempertahankan hak para konseli (para siswa) untuk kepentingan pengadilan dan pengawasan profesionalisme profesi konselor sekolah. Oleh karena itu, menjadi kepentingan strategis mendokumentasikan proses bimbingan dan konseling sebagai hasil penelitian utuh.

Para siswa sebagai konseli didorong untuk berkolaborasi dalam proses konseling secara profesionalisme utuh. Tentu saja kondisi ini perlu dibangun sendari awal dengan siswa. Hubungan profesionlisme menempatkan siswa sebagai konseli bukan antara siswa kepada pendidik. Kenyataan ini akan menjadi dilematis karena relasi yang biasanya terbangun di institusi pendidikan adalah tradisi pendidik dengan siswa. Para siswapun pada akhirnya menganggap konselor sekolah sebagai pendidikpula padahal hubungan antara konselor sekolah dengan konseli sangat berbeda.

\section{DISKUSI}

Pada uraian sebelumnya dalam kajian literatur penulis telah mengemukakan tentang hadist akhir zaman yang berhubungan permasalahan siswa dan peran konselor sebagaimana diungkapkan Bor (2002). Sekarang yang menjadi pertanyaan mendasar adalah bagaimana seorang konselor melihat perspektif gambaran permasalahan siswa berdasarkan hadist akhir zaman, dengan memodifikasi pandangan Bor, at. al (2002) kita akan dapat menyusun alur yang jelas terhadap kondisi yang dihadapi oleh konselor ketika berhadapan dengan siswa yang berada pada akhir zaman.

1) Penanganan konselor sekolah sangat kompleks dan beragam yang menyangkut permasalahan mendalam menyentuh segi-segi kemanusiaan berupa kemunduran krisis sosial, kriminalitas dan penyalahgunaan obat-obatan terlarang, dengan penuh kesadaran, sehingga para konselor perlu memperhatikan adanya hubungan pemberian bantuan, perkembangan hidup pada manusia, dan beberapa isu-isu yang 
sedang beredar (Trisnowati, 2016, p. 172). Semua hal tersebut merupakan fitnah yang menimpa umat manusia yang semuanya berawal dari pengembangan rekadaya khamar (narkoba) sebagaimana dikemukakan dalam hadist akhir zaman yang telah dikemukakan.

2) Bagi siswa tentunya hal ini tidak terlepas dari permasalahan kehidupan berkeluarga dan sikap hidup berkeluarga, yang dapat ditemui dari hadist Rasulullah Saw tentang melunturnyanya adab yang kemudian berdampak pada akhlak, krisis relasi antara hubungan sosial yang mengarah pada sikap hidup individualistik. Oleh karena itu, penekanan pendidikan karakter merupakan salah satu solusi yang bisa diterapkan. Wangid (2010) mengemukakan peran konselor dalam pendidikan karakter yang bisa diambil diantaranya melalui kegiatan pelayanan bimbingan dan konseling di sekolah dengan tetap berpatokan pada nilai dan norma Islam secara umum. Promosi nilai dan norma Islam secara lebih jauh menempatkan peran sekolah dalam menempatkan pada visi dan misi sekolah sebagai tujuan akhir dari sekolah.

3) Konteks sosial yang tekan akan menempatkan konselor berperan lebih luas, mengingat guru BK dan konselor di Indonesia tidak bebas nilai. Prosedur pelayanan bimbingan dan konseling yang berbasis konteks sosial pada fase awal bisa jadi ditempatkan pada pelaksanaan bimbingan dan konseling kearifan lokal dan lintas budaya. Mengingat pelaksanaan bimbingan dan konseling dalam konteks sosial menekana pelayanan bimbingan dan konseling diberikan kepada siswa yang muslim. Namun pada posisi ini apabila dilakukan kelemahannya adalah mengorbankan ajaran Islam sebagai agama dakwah, maka situasi dan kondisi konselor ketika berinteraksi di lapangan perlu dikaji lagi secara mendalam, sehingga makna niche yang dalam pandangan Gumilang (2017) yang berkutat hanya pada peran profesi dan pemaknaan fungsi bimbingan dan konseling tetapi juga konteks ajaran religi khususnya ajaran agama Islam yang dikenal sebagai agama dakwah.

4) Telah dikemukakan sebelumnya bimbingan dan konseling di Indonesia tidak bebas dari nilai, sehingga konselor sangat berperan dalam membantu siswa memiliki corak pandang yang tidak destruktif. Terutama dengan menguatnya dunia hiburan (entertainment) yang nyata-nyata telah menggerus nilai tradisional kehidupan berkeluarga, bermasyarakat dan makna keteladanan, yang mengarah pada kerusakan akhlak dan kepribadian. Oleh karena itu, konselor perlu melakukan upaya massif yang menekankan relasi interpersonal yang kuat antara konselor dengan siswa dan guru mata pelajaran. Seperti yang disarankan oleh Defila, Susanti, dan Wulandari (2012) terletak pada kekuatan intensitas hubungan interpersonal antara guru dengan siswa yang dibimbingnya.

\section{SIMPULAN}

Peran konselor dalam perspektif hadist akhir zaman ternyata memiliki dimensi yang luas dan berimplikasi luas. Hal ini terkait dengan sejumlah hadist yang memaparkan hadist akhir zaman yang meliputi perkembangan narkoba, berkembangnya dunia hiburan yang mempunyai segi-segi merusak, melemahnya akhlak, meluasnya pergaulan bebas dan sikap individualisme. Oleh karena itu, tantangan konselor juga sangat berat untuk dihadapi. Solusi praktis yang bisa dilakukan adalah melalui pengembangan pendidikan karakter dalam pelayanan bimbingan dan konseling dengan penerapan nilai- 
nilai ajaran Islam, tetapi juga perlu memperhatikan esensi ajaran Islam sebagai agama dakwah.

\section{REFERENSI}

Al-Mubayyadh, M. A. (2014). Ensiklopedi akhir zaman (Trans. Ahmad Dzulfikar \& Irwan Raihan). Solo: Granda Mediatama. (Al-Mausu'ah fi Al-Fitan wa Al-Malahim wa Asyrath As-Sa'ah. Original works published 2006).

Azhim, S. A. (2004). Peristiwa-peristiwa dahsyat akhir zaman (Berdasarkan dalil-dalil sahih) (Trans. Hawin Murtadho). Solo: Al Qowam dan Pustaka Barokah. (Amarat as-Sa'ah al-Atiyah. Original works published 2002).

Bor, R. (Ed.) (2002). Counselling in schools. London, Thousand Oaks, New Delhi: SAGE Publications.

Defila, F., Susanti, L., \& Wulandari, R. (2012). Peranan guru dalam bimbingan dan konseling sekolah. (Unpublished paper) STKIP PGRI Sumatera Barat, Padang, Indonesia.

Gumilang, G. S. (2017). Niche Konselor di Indonesia dalam pendidikan formal. Jurnal Fokus Konseling, 3(2), 194-204.

Ihsan, M. (2018). Mendudukkan hadits akhir zaman dengan realita. Retreived Januari 26, 2018, from https://www.kiblat.net/2018/01/27/mendudukkan-hadits-akhir-zamandengan-realita/

Imam Az-Zabidi, Z. A. (2006). Ringkasan Sahih Al Bukhari (Trans. Cecep Syamsul Hari dan Thalib Anis). Bandung: Mizan. (Mukhtashar Shahih Bukhari. Original works published $\mathrm{tt})$.

Mahdi. (2017). Peran guru bimbingan dan konseling dalam meningkatkan kesuksesan belajar siswa di SMA Negeri 1 Depok Sleman Yogyakarta. JURNAL EDUKASI: Jurnal Bimbingan Konseling, 3(1), 1-15.

Muslim, Al Imam. (2005). Terjemahan Hadits Sahih Muslim Jilid 1, 2, 3, 4. (Trans. Ma'mur Daud). Kuala Lumpur: KBC. (Al-Jami`ash-Shahih. Original works published tt).

Nurihsan, A. J. (2006). Bimbingan dan konseling dalam berbagai latar kehidupan. Bandung: Refika Aditama.

Peraturan Menteri Pendidikan dan Kebudayaan Republik Indonesia Nomor 111 Tahun 2014 tentang Bimbingan dan Konseling pada Pendidikan Dasar dan Pendidikan Menengah.

Peraturan Menteri Pendidikan Nasional Republik Indonesia Nomor 27 Tahun 2008 tentang Standar Kualifikasi Akademik dan Kompetensi Konselor. 
Redjeki, S. (2013). Pengembangan karakter melalui pelayanan bimbingan dan konseling. Majalah Ilmiah Pawiyatan, 20(3), 47-57.

Rohman, A. (2016). Peran bimbingan dan konseling Islam dalam pendidikan. Jurnal Progress: Jurnal Pendidikan Agama Islam, 4(1), 136-155.

Setiawan, M. B. (2018). Urgensi Mempelajari Hadits Akhir Zaman. Retrieved April 25, 2018, from https://www.hidayatullah.com/kajian/oaseiman/read/2018/04/25/141200/urgensi-mempelajari-hadits-akhir-zaman.html

Tim Penyusun. (2007). Rambu-rambu penyelenggaraan bimbingan dan konseling dalam jalur pendidikan formal. Jakarta: Direktorat Jenderal Peningkatan Mutu Pendidikan dan Tenaga Kependidikan Departemen Pendidikan Nasional.

Tohirin. (2013). Bimbingan dan konseling di sekolah dan madrasah (Berbasis integrasi). Jakarta: Rajawali Pers.

Trisnowati, E. (2016). Peran konselor di berbagai setting sekolah. Jurnal Konseling Gusjigang, 2(2), 165-172.

Wangid, M. N. (2010). Peran konselor sekolah dalam pendidikan karakter. Jurnal Cakrawala Pendidikan, 29(3), 173-186. 